\title{
Evaluation of Daily Life Activities and Life Qualities of Ventricular Assist Device Installed Patients*
}

\author{
Ventrikül Destek Cihazı Takılan Hastaların Günlük Yaşam Aktiviteleri ve Yaşam \\ Kalitelerinin Değerlendirilmesi*
}

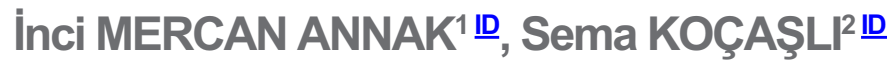

\author{
IMA: 0000-0002-1327-8875 SK: 0000-0002-5718-0669 \\ ${ }^{1}$ Yüksek İhtisas Üniversitesi, Sağllk Hizmetleri Meslek Yüksekokulu, Ankara/ Türkiye \\ ${ }^{2}$ Ankara Yıldırım Beyazıt Üniversitesi, Sağlık Bilimleri Fakültesi, Hemşirelik Bölümü, Ankara/ Türkiye
}

\begin{abstract}
Conscious and professional nursing practices both during hospitalization period and after discharge have a great importance for preventing the possible complications with Ventricular Assist Device (VAD) and for maximizing the life quality. This research was conducted for the purpose of evaluating the daily life activity levels and the life qualities of the ventricular assist device installed patients.

The research is a cross-sectional type descriptive research and it was conducted with 31 ventricular assist device patients who accepted to participate the research. It was used Patient Identification Form, SF 36 Life Quality Scale, KATZ Daily Life Activities Scale and EQ-5D General Life Quality Scale for data collection. Research data was collected from the VAD installed patients who come for their medical examinations to cardiovascular polyclinics and who have not been discharged yet after the transaction through face to face interviews by creating a noiseless and peaceful environment between the dates of May 2015 and November 2015. The data obtained from the study was evaluated through SPSS 20 package program. In the data evaluation, it was used Mann Whitney U and Kruskal Wallis-H Tests, Chi-square analysis, Fisher's Exact Test and Pearson Chi-square analysis. In evaluating the result, the significance level was evaluated as $\mathrm{p}<0.05$.

It was specified that $80.6 \%(n=25)$ of the patients who participated the study experienced rehospitalization and the reasons of rehospitalization of $35.5 \%(n=11)$ is infection, of $25.8 \%(n=8)$ is thrombus and of $22.5 \%(n=7)$ is device problems. It was seen that $70.9 \%$ of the patients felt themselves good after the device installation. While the life qualities of the patients were founded as median according to the SF 36 Life Quality Scale and EQ5D General Life Quality Scale, it was identified that 71.0\% $(n=22)$ of them perform their daily life activities independently according to the KATZ Daily Life Activities Scale.

It was identified that the patients became more independent, felt their health better and their life quality is increased than before the VAD.
\end{abstract}

Keywords: nursing, heart-assist devices, quality of life, nursing care

\section{Özet}

Ventrikül Destek Cihazı (VAD) ile gelişebilecek komplikasyonları önlemek ve yaşam kalitesini en üst düzeye getirmek için, hem hastane sürecinde hem de taburculuk sonrası dönemde bilinçli ve profesyonel hemşirelik uygulamaları büyük önem taşımaktadır. Bu araştırma VAD takılan hastaların günlük yaşam aktivite düzeylerini ve yaşam kalitelerini değerlendirmek amacıyla yapılmıștır.

Kesitsel tipte tanımlayıcı olan araştırma VAD takılan, araştırmaya katılmayı kabul eden 31 hasta ile gerçekleştirildi. Veri toplama aracı olarak Hasta Tanitım Formu, SF 36 Yaşam Kalitesi Ölçeği, KATZ Günlük Yaşam Aktiviteleri Ölçeği ve EQ-5D Genel Yaşam Kalitesi Ölçeği kullanıldı. Araştırma verileri Mayıs 2015-Kasım 2015 tarihleri arasında VAD takılan, kalp damar cerrahisi polikliniklerinde kontrollerine gelenler ile işlem sonrası hastaneden henüz taburcu olmayan hastalardan, gürültüden uzak ve rahat bir ortam yaratılarak, yüz yüze görüşme ile toplandı. Çalışmadan elde edilen veriler SPSS 20 paket programında değerlendirildi. Verilerin değerlendirilmesinde Mann Whitney U ve Kruskal Wallis-H Testleri, Ki-Kare analizi, Fisher's Exact Test ve Pearson Ki Kare analizleri kullanıldı. Sonuçlar yorumlanırken anlamllık düzeyi $\mathrm{p}<0.05$ olarak değerlendirildi.

Çalışmaya katılan hastaların \%80.6'sının ( $\mathrm{n}=25)$ yeniden hastaneye yatış yaptığı ve bu yatış nedenleri arasında \% $35.5^{\prime} \mathrm{inin}(\mathrm{n}=11)$ enfeksiyon, $\% 25.8^{\prime} \mathrm{inin}(\mathrm{n}=8)$ trombüs ve $\% 22.5^{\prime} \mathrm{inin}(\mathrm{n}=7)$ cihaz sorunları olduğu saptandı. Hastaların \%70.9'unun cihaz takıldıktan sonra kendilerini daha iyi hissettikleri görüldü. SF 36 Yaşam Kalitesi Ölçeği ve EQ-5D Genel Yaşam Kalitesi Ölçeğine göre hastaların yaşam kaliteleri orta olarak bulunurken, KATZ Günlük Yaşam Aktiviteleri Ölçeğine göre de \%71.0’inin ( $\mathrm{n}=22$ ) bağımsız olarak günlük yaşam aktivitelerini gerçekleştirdikleri saptandı.

VAD öncesine göre hastaların daha bağımsız hale geldiği, sağlıklarını daha iyi buldukları ve yaşam kalitelerinin arttı̆̆ı saptandı.

Anahtar Kelimeler: hemşirelik, kalp destek cihazları, yaşam kalitesi, hemşirelik bakımı 


\section{INTRODUCTION}

According to World Health Organization (WHO), cardiac insufficiency is defined as a syndrome emerged as a result of the filling the ventricles with blood and/or the breakdown of their blood pumping property due to the structural and/or functional failure of the heart $(1,2)$. It is reported that there are 5 million cardiac insufficiency patients and it is added 550.000 new cardiac insufficiency cases per year in United States of America (USA) $(3,4)$. It is estimated that there are 800.000 cardiac insufficiency patients and 3.000 of these patients have end-stage cardiac insufficiency in Turkey.

When there is no option for any other treatment in cardiac insufficiency patients, the last treatment option for extending the recovery and increasing the life quality is the heart transplantation. In Turkey, the heart transplantation rate is 1.1 per one million population for the year of 2010 (5). It was performed nearly 54.000 heart transplantations across the world until today. The number of patients waiting for organ transplantation is approximately one billion $(5,6)$. This situation necessitates to make live the patients during while they are waiting for transplantation as well as turning towards alternative treatment methods. Especially the technological progress increased in the recent period causes a rapid development of mechanical circulatory supports, an increase in surgical techniques such as ventricular assist device (VAD) implantation and an extensity in using these techniques.

The symptoms of the patients can be minimized through VAD, and the VAD affects the pressure/volume relation of the relevant circulatory system about the disease positively, it causes reductions in the wall thickness of left ventricle and the volumes, it reduces the antibodies of anti-adrenoceptors as well as increasing the response against adrenaline, making regress the left ventricle hypertrophy, and restoring the patients to a condition of performing their daily life activities easefully (7-11).

Even though the life qualities of the patients increase seriously after the VAD surgery, it also has negativities such as that it has many complications which increase mortality, that it is unfeasible to uninstall the device when it can not find any donor, and that it does not enable a complete recovery $(9,10,12,13)$. For this reason, conscious and professional nursing practices both during hospitalization period and after discharge have a great importance for preventing the possible complications and for maximizing the life quality. It is thought that this study will make a significant contribution for the nurses in giving efficient, qualified and evidence-based care about the VAD because of that there is no enough literature resource due to the fact that VAD is a recently increasing treatment in Turkey.

\section{MATERIAL and METHODS}

This research was conducted for the purpose of evaluating the Daily life activity levels and the life qualities of the ventricular assist device installed patients as a cross-sectional type research. For conducting the research, it was received ethical approval from Ankara Yıldırım Beyazit University Ethical Committee (15324997/176) and written permissions from Başkent University Ankara Hospital (31220125/222), Ankara University Cebeci Research and Application Hospital (53756990-806.01.03[806.01.03]17769) and Turkey Yüksek İhtisas Education and Research Hospital (B.10.4.İSM.4.06.00.15.1-PKK 619) and it was received written consent from the patients after informing them. The study was carried out in accordance with the principles of the Helsinki Declaration.

Because of that VAD device installation transaction has begun in 2012 in the city the research was conducted, the research population was consisted of all the patients to whom the VAD is installed (46 patients) between the years of 2012 and 2015. The reason why these hospitals were chosen for the study is that the VAD installation is performed only in these hospitals. 2 of the patients did not accpet to participate the study, 12 of them could not be contacted because of they did not come for their medical examinations for the reason that they are out of town, and 1 patient was left out of the sample because of being 0-10 years old. For this reason, the research sample consists of 31 patients who volunteer for participating the research and meet the research criteria. Research data was collected from the VAD installed patients who come for their medical examinations to cardiovascular polyclinics and who have not been discharged yet after the transaction through face to face interviews by creating a noiseless and peaceful environment between the dates of May 2015 and November 2015. The application of surveys and scales took for 15-20 minutes. When the patients did not understand the questions, they were explained by the researcher.

Data was collected through using Patient Identifica- 
Table 1. Distribution of the socio-demographical features of the patients $(n=31)$.

\begin{tabular}{|c|c|c|}
\hline Demographic features & $\mathbf{n}$ & $\%$ \\
\hline \multicolumn{3}{|l|}{ Gender } \\
\hline Female & 7 & 22.6 \\
\hline Male & 24 & 77.4 \\
\hline \multicolumn{3}{|l|}{ Age groups } \\
\hline $10-20$ & 9 & 29.0 \\
\hline $21-30$ & 2 & 6.5 \\
\hline $41-50$ & 9 & 29.0 \\
\hline $51-60$ & 11 & 35.5 \\
\hline \multicolumn{3}{|l|}{ Educational status } \\
\hline İlliterate & 1 & 3.2 \\
\hline Primary education & 19 & 61.3 \\
\hline High school & 6 & 19.4 \\
\hline University & 5 & 16.1 \\
\hline \multicolumn{3}{|l|}{ Marital status } \\
\hline Married & 18 & 58.1 \\
\hline Single & 13 & 41.9 \\
\hline \multicolumn{3}{|l|}{ Working status } \\
\hline Working & 6 & 19.4 \\
\hline Not working & 20 & 64.5 \\
\hline Stop working & 5 & 16.1 \\
\hline \multicolumn{3}{|l|}{ Smoking } \\
\hline Yes & 4 & 12.9 \\
\hline No & 16 & 51.6 \\
\hline I quit & 11 & 35.5 \\
\hline \multicolumn{3}{|l|}{ Concomitant diseases * } \\
\hline Diabetes mellitus & 4 & 12.9 \\
\hline Hypertension & 5 & 16.1 \\
\hline Cholesterol & 3 & 9.7 \\
\hline $\begin{array}{l}\text { Other (inguinal hernia, migraine, breast cancer, hypotension } \\
\text { etc.) }\end{array}$ & 6 & 19.3 \\
\hline \multicolumn{3}{|l|}{ BMI (body mass index) } \\
\hline$<18.5$ (thin) & 6 & 19.3 \\
\hline $18.5-25.0$ (normal) & 13 & 41.9 \\
\hline $25.0-30.0$ (overweight) & 9 & 29.0 \\
\hline$>30.0$ (obese) & 3 & 9.8 \\
\hline \multicolumn{3}{|l|}{ Compliance to diet program } \\
\hline Complying with diet & 27 & 87.1 \\
\hline Not complying with diet & 4 & 12.9 \\
\hline \multicolumn{3}{|l|}{ Surgery date (how many months before) } \\
\hline $0-6$ & 11 & 35.5 \\
\hline $7-12$ & 9 & 29.0 \\
\hline $13-18$ & 4 & 12.9 \\
\hline $19-24$ & 2 & 6.5 \\
\hline 25 and over & 5 & 16.1 \\
\hline \multicolumn{3}{|l|}{ Hospitalization period (month) } \\
\hline $0-1$ & 16 & 51.6 \\
\hline $1-2$ & 10 & 32.3 \\
\hline 2 and over & 5 & 16.1 \\
\hline \multicolumn{3}{|l|}{ Rehospitalization } \\
\hline Yes & 25 & 80.6 \\
\hline No & 1 & 3.3 \\
\hline Not discharged & 5 & 16.1 \\
\hline \multicolumn{3}{|l|}{ Rehospitalization frequency after discharge $(n=25)$} \\
\hline 1 & 14 & 56.0 \\
\hline 2 & 6 & 24.0 \\
\hline 3 & 5 & 20.0 \\
\hline \multicolumn{3}{|l|}{ Reason of hospitalization* } \\
\hline Infection & 11 & 35.5 \\
\hline Thrombus & 8 & 25.8 \\
\hline Device problem & 7 & 22.5 \\
\hline $\begin{array}{l}\text { Other (hemorrhage, gynecological diseases, medical } \\
\text { examination etc.) }\end{array}$ & 10 & 32.3 \\
\hline
\end{tabular}

tion Form which includes information about the individual and the diseases prepared as a result of the literature review (14-23), SF 36 Life Quality Scale, KATZ Daily Life Activities Scale and EQ-5D General Life Quality Scale. The patient identification form has 18 questions in total including 10 questions about the socio-demographical features of the patients and 8 questions about the features of the disease.

SF 36 Life Quality Scale was developed by Ware in 1987 (24) and its validity-reliability study was conducted by Koçyiğit et al. in our country (25). The scale consists of 36 items and 8 dimensions. These dimensions are; physical function (10 items), social function (2 items), role limitation due to physical functions (4 items), role limitations due to emotional problems (3 items), mental health (5 items), energy/vitality (4 items), pain (2 items), and general perception of health (5 items) (26).

KATZ Daily Life Activities Scale (GYA) was developed by Katz et al. (1963) (27) and its validity-reliability study and Turkish adaptation were conducted by Kaplan (28). This scale consists of 10 titles including cleaning, shopping, transportation, food preparation, etc. $(27,29)$.

EQ-5D General Life Quality Scale was developed by Euro Qol group which is the Western Europe Life Quality Research Society (30) and its validity-reliability for Turkish was conducted by Kahyaoğlu (2009) (31). The scale consists of two sections. EQ-5D General Life Quality Scale consists of 5 dimensions including mobility, self-care, usual activities, pain/discomfort, and anxiety/ depression. It is calculated the index score ranging between -0.59 and 1 from its 5 dimensions. In the score

* More than one option was marked 
function, while 0 score indicates the death and 1 score indicates the perfect health, negative scores indicates the situations such as the blackout, living bedridden etc. EQ-5D General Life Quality Scale is a Visual Analogue Scale by which the individuals give values about their present health status between 0 and 100, and mark them on a thermometer-like scale. It is obtained life quality scores ranging between $o$ and 100 through the scale (30).

Data analysis was conducted in SPSS 20 (Statistical Package for the Social Sciences) package program. In the data evaluation, it was used Mann Whitney $U$ and Kruskal Wallis-H Tests, Chi-square analysis, Fisher's Exact Test and Pearson Chi-square analysis. In evaluating the result, the significance level was evaluated as $\mathrm{p}<0.05$.

\section{LIMITATIONS OF THE RESEARCH}

The limitations of the study are that some of the patients with VAD living outside the province and not being able to come to their controls regularly and grouping is not possible due to the small number of patients and therefore the wide age range.

\section{RESULTS}

In Table 1, it was identified that $77.4 \%(\mathrm{n}=24)$ of the patients are male, $22.6 \%$ of them $(n=7)$ are female; $35.5 \%$ of them $(n=11)$ are in the age group of $51-60$. It was specified that $64.5 \%$ of the patients $(n=20)$ are primary school graduate and lower, $19.4 \%(\mathrm{n}=6)$ are high school graduate, $16.1 \%$ are $(n=5)$ are university graduate; and $58.1 \%$ of them $(\mathrm{n}=18)$ are married (Table 1$)$.
It was identified that $29.0 \%(\mathrm{n}=9)$ of the patients experienced asthenia, $25.8 \%(\mathrm{n}=8)$ experienced charging problem about the device, $19.4 \%(n=6)$ experienced pain and tachycardia; and the rate of incidence of other problems which are grouped as blackout, respiratory disorder, nausea and vomit is $25.8 \%$ (Figure 1 ).

In Figure 2, while 54.8\% $(\mathrm{n}=17)$ of the patients feel themselves better as regards before VAD; $9.7 \%$ of them $(n=3)$ express that they feel themselves worse as regards before the surgery.

The life qualities of the patients were found as median according to SF 36 Life Quality Scale, and EQ-5D General Life Quality Scale, and it was seen that 71.0\% $(n=22)$ of the patients perform their daily life activities independently according to the KATZ Daily Life Activities Scale (Table 2).

In Table 3, the majority of those who fulfill their self-care needs except washing/bathing dependently before VAD can fulfill their need independently after $\operatorname{VAD}(\mathrm{p}>0.05)$. As for the patients who were independent before VAD, it was identified that $35.0 \%(n=7)$ of them are independent, $65.0 \%(n=13)$ of them are dependent in their washing/bathing needs; and as for the patients who were dependent before VAD, it was identified that $45.5 \%(n=5)$ of them are independent and $54.5 \%(n=6)$ of them are dependent in their washing/bathing needs ( $\mathrm{p}>0.05$ ) (Table 3 ).

The scores of the primary education graduate and lower patients on physical condition and physical role limitation which are two of sub-steps of SF-36 Life Quality Scale are significantly lower than the scores of high school graduate and higher patients $(\mathrm{p}<0.05)$.

Figure 1. Distribution of the common problems in the patients after VAD $(n=31)$

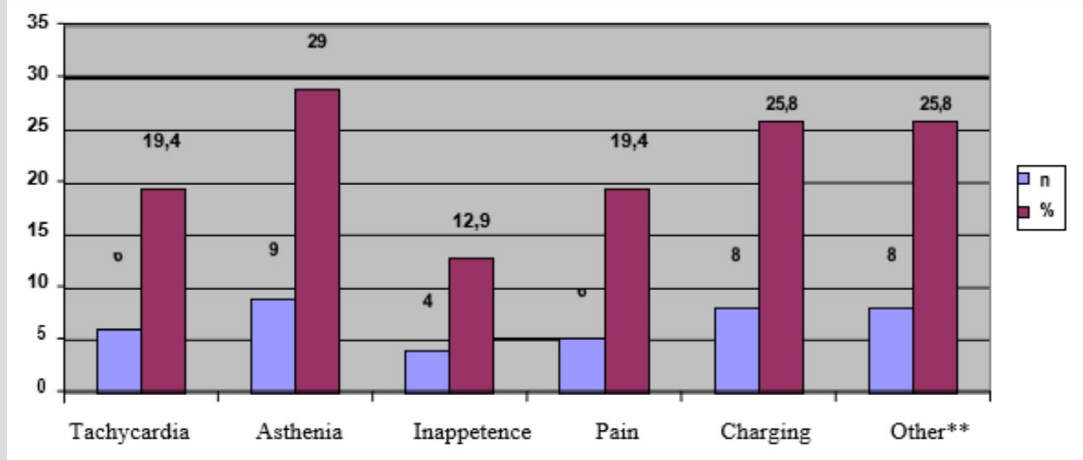

*More than one option was marked. **Blackout, respiratory disorder, nausea, vomit 
Figure 2. Distribution of patients' perception of their present health status as regard before VAD $(n=31)$.
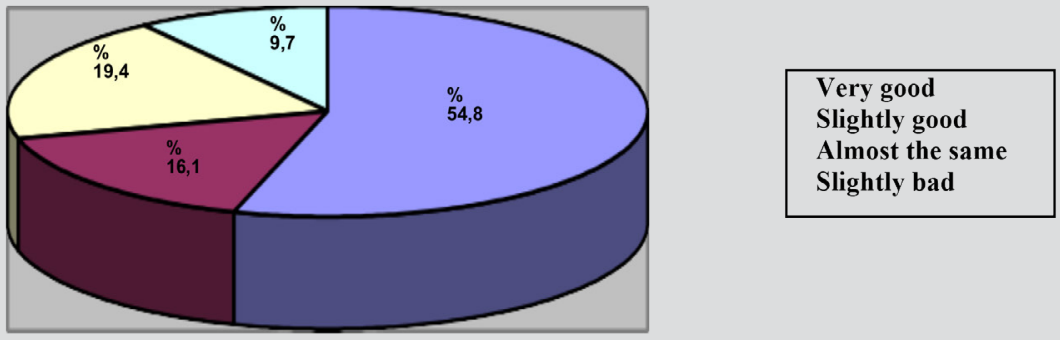

There is statistically significant difference between their EQ 5D index scale score and their educational status $(\mathrm{p}<0.05)$. EQ 5D index scale score of the high school graduate and higher patients is significantly lower than the primary education graduate and lower patients.

It could not be found an expected statistical significance because of the research is based on a small sample group. However, the results indicate that the patients became more independent, they felt their health better and their life quality increased as regards before VAD. In this context, it is thought that long-term or end-stage therapeutic
VAD installation has positive influences on life quality.

\section{DISCUSSION}

Some complications to be seen after recovery in the patients in post-VAD surgery period $(13,32,33)$. In various studies, it was seen that infection $(14,18)$, thrombus and infection $(19,34)$, hemorrhage (21), and hemorrhage and thrombus (35) are among these complications. It was identified that the majority of the patients participated in our research re-hospitalized with some complications after discharge, and $56.0 \%$ of them were re-hos-

Table 2. Distribution of SF 36 Life Quality Scale, EQ-5D General Life Quality Scale and KATZ Daily Life Activities Scale scores ( $n=31)$.

\begin{tabular}{|c|c|c|c|c|c|c|}
\hline SF-36 Questionnaire Form & \multicolumn{2}{|c|}{ Ave \pm SD* } & \multicolumn{2}{|c|}{ Median } & Min & Max \\
\hline Physical function & \multicolumn{2}{|c|}{$28.87 \pm 15.95$} & \multicolumn{2}{|c|}{35.0} & 0 & 50.0 \\
\hline Physical role limitation & \multicolumn{2}{|c|}{$19.35 \pm 32.73$} & \multicolumn{2}{|c|}{0} & 0 & 100.0 \\
\hline Emotional role limitation & \multicolumn{2}{|c|}{$23.66 \pm 34.63$} & \multicolumn{2}{|c|}{0} & 0 & 100.0 \\
\hline Pain & \multicolumn{2}{|c|}{$66.28 \pm 17.91$} & \multicolumn{2}{|c|}{72.8} & 18.2 & 81.8 \\
\hline Mental health & \multicolumn{2}{|c|}{$41.51 \pm 9.30$} & \multicolumn{2}{|c|}{43.3} & 23.3 & 56.7 \\
\hline Vitality (energy) & \multicolumn{2}{|c|}{$34.68 \pm 16.19$} & \multicolumn{2}{|c|}{29.2} & 0 & 62.5 \\
\hline General health & \multicolumn{2}{|c|}{$38.97 \pm 8.26$} & \multicolumn{2}{|c|}{40.0} & 24.0 & 56.0 \\
\hline Social function & \multicolumn{2}{|c|}{$55.65 \pm 30.08$} & \multicolumn{2}{|c|}{62.5} & 0 & 100.0 \\
\hline \multicolumn{7}{|l|}{ EQ-5D General Life Quality Scale } \\
\hline EQ 5D index scale & \multicolumn{2}{|c|}{$0.32 \pm 0.17$} & \multicolumn{2}{|c|}{0.3} & 0.08 & 0.8 \\
\hline EQ 5D VAS (Visual Analogue Scale) scale & \multicolumn{2}{|c|}{$69.35 \pm 20.36$} & \multicolumn{2}{|c|}{70.0} & 30.0 & 100.0 \\
\hline \multirow[t]{2}{*}{ Katz Daily Life Activities Scale } & \multicolumn{2}{|c|}{ Dependent } & \multicolumn{2}{|c|}{$\begin{array}{c}\text { Partly } \\
\text { Dependent }\end{array}$} & \multicolumn{2}{|c|}{ Independent } \\
\hline & $\mathbf{n}$ & $\%$ & $\mathbf{n}$ & $\%$ & $\mathbf{n}$ & $\%$ \\
\hline Cleaning & 6 & 19.4 & 9 & 29.0 & 16 & 51.6 \\
\hline Shopping & 6 & 19.3 & 6 & 19.3 & 19 & 61.4 \\
\hline Transportation & 4 & 12.9 & 13 & 41.9 & 14 & 45.2 \\
\hline Food Preparing & 6 & 19.4 & 4 & 12.9 & 21 & 67.7 \\
\hline Bathing & 3 & 9.7 & 16 & 51.6 & 12 & 38.7 \\
\hline Dressing & 1 & 3.2 & 10 & 32.3 & 20 & 64.5 \\
\hline Visiting the toilet & 1 & 3.2 & 6 & 19.4 & 24 & 77.4 \\
\hline Transfer & 1 & 3.2 & 5 & 16.2 & 25 & 80.6 \\
\hline Continence & 0 & 0 & 5 & 16.2 & 26 & 83.8 \\
\hline Nutrition & 0 & 0 & 4 & 12.9 & 27 & 87.1 \\
\hline General Scoring & 1 & 3.2 & 8 & 25.8 & 22 & 71.0 \\
\hline
\end{tabular}

*Ave $\pm S D$ : Average \pm Standard deviation 
pitalized once and $44.0 \%$ of them were re-hospitalized more than once. It is seen that $35.5 \%$ of the hospitalization reasons is infection, $25.8 \%$ is thrombus, and $22.5 \%$ is device problems. While this situation is consistent with the literature, it makes us think that a comprehensive and effective nursing care for the patients including the post-discharge period is quite important, that the complication rate will increase in parallel with this care, and that it will prevent rehospitalizations in the least.

VAD installed patients can perform many activities which they could not do previously because of the cardiac insufficiency such as cycling, walking and dancing, they can return their previous life styles, and they become more independent $(19,36,37)$. As in the studies on VAD installed patients of Dew et al. (2000), Grady et al. (2003) and Kitko et al. (2015), most of the patients $(70.9 \%)$ express that they feel themselves better after the installation of device $(16,22,38)$. This situation makes us think that there is a reduction in the symptoms of the physical, psychological and sociological problems faced by the patients in spite of the negativities accompanying the device (such as the charging and cable problem of the device) and therefo- re there is an improvement in their life qualities. Our finding indicates how the life of the patients improve even with a device that have a similar prognosis except transplantation as well as indicating how it is important to raise the awareness of the society about organ transplantation. It is thought that the life quality of the patients will improve in emotional, physical and social dimensions correspondingly.

The patients have not been fulfilling their self-care needs easily because of the symptoms caused by the cardiac insufficiency $(39,40,41)$. The patients become more independent with reduction in symptoms, moving easily, and the oxygen supply after VAD (7, 13). In the study conducted by Granegger et al. (2016) on Left Ventricular Assist Device (LVAD), it was specified that the patient can perform their daily life activities like healthy people after the LVAD installation (23). In the study conducted by Casida et al. (2011) for the purpose of researching and defining the life styles of 9 LVAD installed patients, they rank the external factors such as battery or cables among the reasons of the difficulties of the patients to maintain their hygiene habits (17). In our research, it was specified that the patients who perform their eating

Table 3. Comparison of the patients through their self-care needs of the patients before VAD and after VAD $(n=31)$

\begin{tabular}{|c|c|c|c|c|c|}
\hline \multirow{3}{*}{ Before VAD } & \multicolumn{4}{|c|}{ After VAD } & \multirow{3}{*}{$\begin{array}{l}\text { Chi-square } \\
\text { Test } \\
\text { p }\end{array}$} \\
\hline & \multicolumn{2}{|c|}{ Independent } & \multicolumn{2}{|c|}{ Dependent } & \\
\hline & $\mathbf{n}$ & $\%$ & $\mathbf{n}$ & $\%$ & \\
\hline \multicolumn{5}{|l|}{ Eating/Drinking } & \multirow{3}{*}{$1 *$} \\
\hline Independent $(n=27)$ & 26 & 96.3 & 1 & 3.7 & \\
\hline Dependent $(n=4)$ & 4 & 100.0 & 0 & 0 & \\
\hline \multicolumn{5}{|l|}{ Washing/Bathing } & \multirow{3}{*}{$0.537^{*}$} \\
\hline Independent $(n=20)$ & 7 & 35.0 & 13 & 65.0 & \\
\hline Dependent $(n=11)$ & 5 & 45.5 & 6 & 54.5 & \\
\hline \multicolumn{5}{|l|}{ Dressing/Tidying up } & \multirow[b]{3}{*}{$0.106^{*}$} \\
\hline Independent $(n=20)$ & 12 & 60.0 & 8 & 40.0 & \\
\hline Dependent $(n=11)$ & 10 & 90.9 & 1 & 9.1 & \\
\hline \multicolumn{5}{|l|}{ Toilet } & \multirow[b]{3}{*}{$1^{*}$} \\
\hline Independent $(n=19)$ & 16 & 84.2 & 3 & 15.8 & \\
\hline Dependent $(n=12)$ & 11 & 91.7 & 1 & 8.3 & \\
\hline \multicolumn{5}{|l|}{ Bed activities } & \multirow[b]{3}{*}{$0.188^{*}$} \\
\hline Independent $(n=25)$ & 25 & 100.0 & 0 & 0 & \\
\hline Dependent $(n=6)$ & 5 & 83.3 & 1 & 16.7 & \\
\hline \multicolumn{5}{|l|}{ Walking } & \multirow{3}{*}{$1 *$} \\
\hline Independent $(n=19)$ & 17 & 89.5 & 2 & 10.5 & \\
\hline Dependent $(n=12)$ & 11 & 91.7 & 1 & 8.3 & \\
\hline
\end{tabular}


and drinking activity dependently before VAD started to perform that activity $100.0 \%(n=4)$ independently after VAD. Similarly, it was found that the majority of the patients who dress, visit the toilet, walk and do bed activities dependently (\%90.9, \%91.7) before VAD started to perform these activities independently after VAD. It was identified that only $65.0 \%$ of the patients who fulfill their bathing need independently before VAD became dependent after VAD. While these findings are consistent with the literature, it is thought that the situation of becoming dependent in bathing self-care need is due to not being accustomed to the device and the fears about the device such as the possibility of splashing water on the device or stepping on the device cable.

It is seen recoveries in hepatic and renal functions during at least 4-5 weeks after VAD implantation. The symptoms of VAD installed patients decrease, many of them start to perform their daily life activities easily, and their life qualities increase $(36,37)$. In the study conducted by İşkesen et al. (2007) on the patients who have undergone coronary artery surgery, and in the study conducted by Bektaş (2014) on the patients who have undergone open heart surgery in the recent year, SF 36 Life Quality scale score was evaluated as median $(20,42)$. In the study conducted by Buendia et al. (2011) for the purpose of examining the relation between the functional capacity and the life quality in heart transplant patients, the average score of EQ 5D VAS Scale was specified in the 2nd month as $78.93 \pm 16.10$, in the 6th month as $83.80 \pm 11.30$ and in the 12th month as $83.30 \pm 11.10$ (43). However, in our study, the life quality of the patients was specified as median according to SF 36 Life Quality Scale, and EQ5D General Life Quality Scale. The studies in the literature which evaluate the life qualities of the patients through the SF 36 life quality are consistent with our research findings. This situation indicates that the life qualities of the patients increased after the cardiac surgeries. In line with the literature $(16,20,36,37,42,43)$, when the scores given by the patients about their present health status are examined, it is seen that while the patients who have acute coronary syndrome evaluate their health as worse as regards VAD installed patients, the patients who have undergone heart transplantation feel themselves better as regards VAD installed patients. One of the aims of installing VAD is to provide a bridge towards heart transplantation, and this result shows parallelism with the literature.

In the study of Özer (2002), it was specified that the life quality of the patients with high educational status is lower than those who literate or illiterate (15). In the study of Özdemir (2009), there are significant relations between the educational status and some dimensions of life quality (44). The sub-dimensions of physical function and vitality (energy) in SF-36 scale of literate patients was found significantly low. In our study, it was seen that the more the educational level increases the more life quality increases according to SF 36 Questionnaire Form and it was found a statistical significance $(\mathrm{p}<0.05)$. Similarly, there is a statistically significant difference between EQ 5D scale score and the educational status of the patients $(\mathrm{p}<0.05)$. It was seen that the EQ 5D index scale score of the high school graduate and higher patients is significantly lower than the score of the primary education graduate patients. Yet, the score given by the high school graduate and higher patients for their health was founded as higher, and it was identified that the more the educational status of the patients increases the more their independency level increases in Katz Daily Life Activities Scale. In our study, it was found that while the more the educational level increases the more the life quality increases according to SF-36 Questionnaire Form and Katz Daily Life Activities Scale, the life qualities of those who have a high educational level was found as lower in EQ 5D life quality. While these findings are consistent with the literature, it indicates that the more the educational level of the patients increases the more their life quality increases, and they can perform their Daily life activities more independently.

\section{CONCLUSION}

As a result of the study, it can be recommended that it can be conducted studies with more participation in parallel with the increase in device installation, it can be conducted further studies for evaluating the VAD device and the life qualities of the patients because there are limited number of studies about the VAD device and the life qualities of the patients, it can be given trainings to the nurses on the VAD device, its indications, its contraindications and patient care through giving in-service trainings and organizing certification programs and courses.

Received Date/Geliş Tarihi: 19.06.2020

Accepted Date/Kabul Tarihi: 20.07.2020 


\section{REFERANSLAR}

1. Heper C. Multidisipliner Kardiyoloji Kitabı. İstanbul, Nobel \& Güneş, 2002; 323-339.

2. Cankurtaran M, Arığul S. Yaşlıda Konjestif Kalp Yetersizliği Tedavisi. Klinik Gelişim, 2004; 17(2): 90-100.

3. Akın S, Durna Z. Kalp Yetersizliği Hastalarının Psikososyal Uyumu. C.Ü. Hemşirelik Yüksekokulu Dergisi. 2006; 10(2): 1-8.

4. Demir M, Ünsar S. Kalp Yetmezliği ve Evde Bakım. Fırat Saglık Hizmetleri Dergisi. 2008; 3(8): 119-130.

5. TÜİK. Ölüm Nedeni İstatistikleri, 2010, 2011 ve 2012. 2013; 15847. http:// www.tuik.gov.tr/PreHaberBultenleri.do?id=15847 17 Aralık 2015.

6. Kırnap M. Organ Bağıșında Ne Durumdayız? Sağlıkta Adres Başkent. 2011; 4: 11 .

7. Durdu S, Akar R, Çavolli R ve diğ. İleri Dönem Kalp Yetmezliğinde Alternatif Arayışlar. Anadolu Kardiyoloji Dergisi, 2003; 3: 252-260.

8. Vural KM. Ventriküler destek cihazı uygulamaları. Anadolu Kardiyol Derg. 2008; 8(2):117-130

9. Birks EJ. Left Ventricular Assist Devices. Heart. 2010; 96: 63-71.

10. Dickstein K, Vardas PE, Auricchio A ve Veldhuisen DJ. Kalp yetersizliğinde cihaz tedavisi hakkındaki ESC kılavuzlarının 2010 Odaklı Güncellemesi. Türk Kardiyoloji Derneği Arşiv. 2010; 3: 7-18.

11. Özbaran M, Yağdı T. Kalp Nakli ve Diğer Cerrahi Tedaviler. Klinik Gelişim. 2011; $24: 67-75$.

12. Vural K, Öz M. Kalıcı Amaçlı Sol Ventrikül Destek Cihazları: Tcı Heartmate Ve. Türk Göğüs Kalp Damar Cerrahisi Dergisi. 1999; 7(5): 393-401.

13. Puehler T, Ensminger S, Schoenbrodt $M$ ve diğ. Mechanical circulatory support devices as destination therapy current evidence. Annals of Cardiothoracic Surgery. $2014 ; 3(5):$ 513-524.

14. Tjan TDT, Asfour B, Hammel D, Schmidt C, Scheld HH, ve Schmid C. Wound Complications After Left Ventricular Assist Device Implantation. Annals of Thoracic Surgery. 2000; 70: 538-41.

15. Özer S. Kalp Yetmezliğinde Sağlık Davranıșları ve Yașam Kalitesi İlişkisinin İncelenmesi. Sağlık Bilimleri Enstitüsü, Yüksek Lisans Tezi, İzmir: Ege Üniversitesi, 2002.

16. Grady KL, Meyer PM, Dressler D ve diğ. Change in quality of life from after left ventricular assist device implantation to after heart transplantation. J Heart Lung Transplant. 2003; 22: 1254.

17. Casida JM, Marcuccilli L, Peters RM, Wright S. Lifestyle Adjustments of Adults With Long-Term İmplantable Left Ventricular Assist Devices: A Phenomenologic İnquiry. Heart \& Lung: The Journal of Acute and Critical Care. 2011; 40(6): 511-520.

18. Schaffer JM, Allen JG, Weiss ES ve diğ. Infectious Complications After Pulsatile-Flow and Continuous-Flow Left Ventricular Assist Device İmplantation. The Journal of Heart and Lung Transplantation. 2011; 30(2), 164-174.
19. Moazami N, Milano CA, John R ve diğ. Pump Replacement for Left Ventricular Assist Device Failure Can Be Done Safely and is Associated with Low Mortality. Annals of Thoracic Surgery. 2013; 95(2), 500-505.

20. Bektaş CG. Açık Kalp Ameliyatı Sonrası Ortaya Çıkan Yaşam Biçimi Değişikliklerinin Hastaların Yaşam Kalitesine Etkisi. Sağlık Bilimleri Enstitüsü, Yüksek Lisans Tezi İstanbul: İstanbul Bilim Üniversitesi, 2014.

21. Harvey L, Holley CT, John R. Gastrointestinal Bleed After Left Ventricular Assist Device İmplantation: İncidence, Management, And Prevention. Annals of Cardiothoracic Surgery. 2014; 3(5).

22. Kitko LA, Hupcey JE, Birriel B, Alonso W. Patients' decision making process and expectations of a left ventricular assist device pre and post implantation. Heart \& Lung: The Journal of Acute and Critical Care. 2016; 45(2), 95-99.

23. Granegger M, Schloeglhofer T, Ober H, Zimpfer D, Schima H, Moscato F. Daily Life Activity in Patients with Left Ventricular Assist Devices. The International Journal of Artificial Organs. 2016; 39(1), 22-27.

24. Ware JE. SF-36 Health Survey Update. Spine. 2000; 25(24), 3130-3139.

25. Koçyiğit H, Aydemir Ö, Fișek G, Ölmez N, Memiş A. Kısa Form-36 (KF-36)' nın Türkçe versiyonunun Güvenilirliği. İlaç ve Tedavi Dergisi. 1999; 12(2): $102-6$.

26. Koltarla S. Taksim Eğitim ve Araştırma Hastanesi Sağlık Personelinin Yaşam Kalitesinin Araştırılması. Uzmanlık tezi, İstanbul, 2008.

27. Katz S, Ford AB, Moskowitz RW, Jackson BA, Jaffe MW. Studies of İllness in The Aged. The Index of ADL: A Standardized Measure of Biological and Psychosocial Function. Journal of the American Medical Association. 1963; $185,914-919$.

28. Kaplan İ. Yarı Kırsal Alanda Bir Sağlık Ocağına Başvuran Hastalarda Ruhsal Bozuklukların Yeti Yitimi ile İlişkisi. Türk Psikiyatri Dergisi. 1995; 6(3): 169179.

29. Walance M, Shelkey M. Katz Index of Independence in Activities of Daily Living (ADL). Urol Nurs. 2007; 27.1: 93-94.

30. EuroQol Group. EuroQol--a new facility for the measurement of health-related quality of life. Health policy (Amsterdam, Netherlands). 1990; 16(3), 199.

31. Kahyaoğlu Süt H. Akut koroner sendromlu hastalarda yaşam kalitesi: EQ-5D ölçeğinin geçerlilik ve güvenirlik çalışması. MS thesis. 2009

32. Rose EA, Gelijns AC, Moskowitz AJ ve diğ. Long-Term Use of Left Ventricular Assist Device for End-Stage Heart Failure. New England Journal of Medicine. 2001; 345: 1435

33. Engin Ç. Son Dönem Kalp Yetersizliğinde Ventriküler Destek Cihazları. Kalp Yetersizliği Elektronik Haber Bülteni. 2009; 2(3).

34. Koçaşlı S, Mercan İ. Sağ ve Sol Ventricular assist device Takılan Hastanın Postoperatif Dönemdeki Hemşirelik Bakımı. Türk Kardiyoloji Derneği Kardiyovasküler Hemşirelik Dergisi. 2015; 6(9): 91-98.

35. Aras SG, Balcıoğlu Ö, Balakhisiev M ve diğ. LVAD Hastalarında Taburculuk Sonrası INR takip Yönteminin Hasta Konforu ve Komplikasyonlara olan Etkisi. 13. Türk Kalp ve Damar Cerrahisi Kongresi, Hemşirelik ve Fizyoterapist 
Sözlü Bildirileri. 2014

36. Park SJ, Tector A, Piccioni W ve diğ. Left Ventricular Assist Devices as Destination Therapy: A New Look at Survival. Journal of Thoracic and Cardiovascular Surgery. 2005; 129: 9-17.

37. Slaughter MS, Rogers JG, Milano CA. Advanced Heart Failure Treated with Continuous-Flow Left Ventricular Assist Device. New England Journal of Medicine. 2009; 361: 2241-2251.

38. Dew MA, Kormos RL, Winowich S ve diğ. Human Factors İssues İn Ventricular Assist Device Recipients and Their Family Caregivers. American Society for Artificial Internal Organs. 2000; 46: 367-373.

39. Lam CS, Burnett JC, Costello-Boerrigter L, Rodeheffer RJ, Redfield MM. Alternate circulating pro-B-type natriuretic peptide and B-type natriuretic peptide forms in the general population. Journal of the American College of Cardiology. 2007; 49(11):1193-202.
40. Kahraman G, Ural D. Kalp Yetersizliği ve Şok Sendromu. İçinde: Komşuoğlu B, Ural E, Ural D, eds. Klinik Kardiyoloji. 1.Basım, İzmit, Türkiye: Nobel Tip Kitabevleri; 2004, 377-420.

41. Yalçın YA. Birinci Basamakta Nefes Darlığına Yaklaşım. Smyrna Tip Dergisi. $2012 ; 76-78$.

42. İșkesen İ, Yıldırım F, Şirin H. Koroner Arter Bypass Cerrahisinde Kardiyopulmoner Bypass'in Nörokognitif Fonksiyonlara Etkisi. Turkish Journal of Thoracic and Cardiovascular Surgery. 2007; 15(4): 275-280.

43. Buendia F, Almenar L, Martínez-Dolz L ve diğ. Relationship Between Functional Capacity and Quality of Life in Heart Transplant Patients. In Transplantation Proceedings. 2011; 43(6): 2251-2252).

44. Özdemir VA. Kronik Kalp Yetmezliği Olan Hastalarda Yaşam Kalitesinin Değerlendirilmesi, Sağlık Bilimleri Enstitüsü, Hemşirelik Anabilim Dalı, Yüksek Lisans Tezi, İstanbul: Marmara Üniversitesi, 2009. 